\title{
In memoriam: Dr. Hugo R. Amarillo
}

\author{
Marcelo F. Figari*
}

Me toca hoy recordar al querido Hugo AmariIlo, a quien tuve oportunidad de acompañar en su gestión en la Asociación Argentina de Cirugía (AAC), y que lamentablemente desapareció físicamente en octubre de 2017.

Hugo Rubén Amarillo nació el 26 de marzo de 1935. Fue el primero de cinco hermanos varones, hijo de padre argentino y madre española, y -aunque su lugar de nacimiento fue "El Sosneado", cercano a San Rafael, Mendoza- la mayor parte de su vida familiar y profesional se desarrolló en Tucumán, provincia en la que se lo identifica como un hijo dilecto.

Una vez egresado como bachiller del Colegio San Francisco, de San Miguel de Tucumán, ingresó en la recientemente creada Facultad de Medicina de la Universidad Nacional de Tucumán (UNT), de la cual egresó como $3^{\mathrm{a}}$ promoción de médicos en 1959. Comenta su hijo Hugo que fue desde siempre un estudiante muy aplicado y que se ufanaba de haber leído 23 veces el Manual de Fisiología antes de rendir el examen final.

Otra anécdota de su época de estudiante la refiere su gran amigo, el Dr. Arturo Heidenreich.

Habiéndose cerrado temporalmente la facultad en 1955, los alumnos que no pudieron seguir sus estudios en Córdoba solicitaron poder concurrir a las guardias del Hospital Padilla como practicantes para poder afianzar sus conocimientos y adquirir alguna formación práctica. Ello lo llevó a conocer y disfrutar por primera vez del escenario quirúrgico.

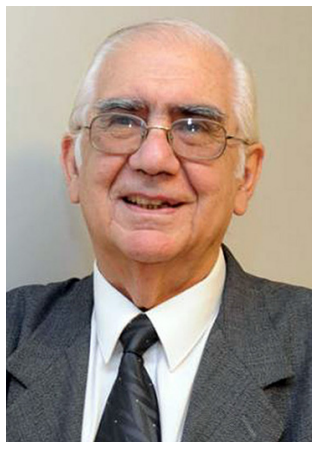

Expresidente de la Asociación Argentina de Cirugía

En su segundo año de práctica pudo ya realizar su primera apendicectomía y es probable que algunas de las experiencias de esa época hayan marcado su futuro como coloproctólogo. El examen de Clínica Quirúrgica, en el $6^{\circ}$ año de su carrera, versó en gran parte sobre megacolon, patología tan frecuente en el NOA (Noroeste Argentino). Y también para esa época realizó, asistido por un médico interno, su primera cirugía de mayor envergadura. Se trataba de una devolvulación sigmoidea y colopexia.

Una vez recibido, Hugo se incorporó al Servicio de Cirugía del Hospital Padilla, que sería el escenario de su crecimiento profesional en los siguientes 58 años.

El Servicio de Cirugía General estaba conducido por Alejandro Torres Posse, recibido en la Universidad de Buenos Aires y formado quirúrgicamente en el Hospital Rawson, en la Escuela Finochietto.

El Hospital Padilla representó su segundo hogar. Todos los que fueron sus compañeros recuerdan a Hugo Amarillo como un cirujano motivado, comprometido, afable, ordenado y de maniobras sencillas y prácticas. Eso llevó al Prof. Torres Posse, quien además conocía su gusto por la cirugía coloproctológica, especialidad con la que no contaba aún el Hospital Padilla, a impulsar a Hugo a formarse en esa dirección.

En 1969 viaja a Buenos Aires para formarse en el Sector de Coloproctología del Hospital Rawson, donde comparte la experiencia con quien sería un gran amigo de por vida, el Dr. Arturo Heidenreich. 
A partir de 1970 regresa al Hospital Padilla, se le asigna un número de camas para el nuevo sector, tan ocupado con el megacolon, y comienza a introducir innovaciones, como el tratamiento ambulatorio de las hemorroides con nuevos procedimientos.

Hugo fue sucesivamente jefe de guardia, jefe de sala y jefe de servicio. Además de haber fundado el primer servicio de coloproctología del NOA, introdujo en 1974 la fibrocolonoscopia (llevó a cabo el primer procedimiento realizado por un cirujano en el ámbito hospitalario) y las anastomosis mecánicas en 1981. En el ámbito asistencial llegó a la posición de jefe de Departamento Quirúrgico del Hospital Padilla.

Paralelamente a su crecimiento profesional, formó una hermosa familia con su compañera de toda la vida, María Cristina Velarde, con quien tuvieron tres hijos: Marcelo, especialista en Diagnóstico por Imágenes; Hugo, quien siguió sus pasos en la Coloproctología, y Fernando, ingeniero informático.

Hugo fue un docente de alma. Inició su carrera como ayudante en la UNT y llegó a ser Profesor Titular de la III Cátedra de Cirugía de la Facultad de Medicina, y luego Profesor Consulto de la Universidad Nacional de Tucumán, donde fue además director del Doctorado y Vicedecano de la Facultad de Medicina.

Su vida académica fue prolífica, a pesar de que no era un hombre que persiguiera títulos. Pero los reconocimientos llegaban.

Su tesis de doctorado fue premiada en 1983. En el año 2004 presidió el Congreso Argentino de Cirugía. El hecho de ser luego Vicepresidente de la AAC en el período 2004-2005 y Presidente en 2005-2006 lo llevó a venir a Buenos Aires con frecuencia semanal. Alguna vez calculó que había realizado unos 171000 km en ómnibus y 62000 km en avión.

Soy testigo de que ese alejamiento repetido de su vida familiar y profesional en Tucumán no lo privaba de mantener una presencia calma, brindando siempre la palabra justa y demostrando una gran afabilidad y sentido del humor.

Durante su gestión en la presidencia de la AAC, donde me otorgó el honor de ser su Secretario General, presencié su desvelo por mantener altos estándares académicos y, a la vez, preocuparse fuertemente por las condiciones laborales de los cirujanos con menos posibilidades y en ámbitos desfavorables.

Fue también reconocido como Miembro Correspondiente Nacional de la Academia Argentina de Cirugía y miembro de la Academia de Ciencias de la Salud de Tucumán. Los últimos grandes reconocimientos a su trayectoria fueron haber sido nombrado Maestro de la Coloproctología Argentina por la Sociedad Argentina de Coloproctología en 2012 y Maestro de la Cirugía Argentina por la Asociación Argentina de Cirugía en 2014.

Hugo Amarillo fue un gran esposo, padre y abuelo, que deja una imagen imborrable en su familia y un modelo para seguir en sus hijos y nietos.

Fue también un gran hacedor, comprensivo y generoso con sus discípulos y con quienes alguna vez cruzamos nuestro camino con él. En épocas en que se resalta como una de las características del líder poder generar en el grupo de colaboradores un buen clima de trabajo y una visión común, quiero rescatar unas palabras de Hugo que su hijo me hizo llegar: "Cuando uno sueña solo, ese sueño es único. Cuando muchos sueñan el mismo sueño existe la posibilidad del cambio".

Gracias, Hugo, por habernos permitido conocerte. 